\title{
Sociologie
}

Sociologie 15(3): $373-376$

(c) De auteur(s) 2019 (c) CC BY NC ND 4.0 () ()ㅇ ()

https://doi.org/10.5117/soc2019.3.009.bos

\section{Boekbespreking \\ Verleden en toekomst van de sociaaldemocratie: Stephanie L. Mudge over breukmomenten in de sociaaldemocratische traditie}

\author{
Maarten van den Bos \\ Banning Vereniging \\ banningvereniging@gmail.com
}

Stephanie L. Mudge (2018) Leftism Reinvented. Western Parties from Socialism to Neoliberalism.

Cambridge: Harvard University Press. 524 pagina's, €44,99, ISBN 9780674971813.
Hoe hebben linkse politieke partijen in het verleden het begrip sociaaldemocratie vorm en inhoud gegeven? Deze vraag stelde de Amerikaanse sociologe Stephanie L. Mudge zich in haar indrukwekkende studie Leftism Reinvented, waarin de ideologische oriëntaties van de Amerikaanse Democratische partij, het Britse Labour, de Duitse SPD en de Zweedse Socialdemokraterna centraal staan. Mudge gaat op zoek naar constanten en transformaties in het zelfbeeld en politieke taalgebruik vandezevierpartijen en komt totdeconclusiedatin deze geschiedenis twee breukmomenten zijn aan te wijzen. In de jaren dertig, toen de partijen het materialistisch determinisme van Marx inruilden voor een op Keynes gebaseerde economische interventiepolitiek. En in de jaren tachtig en negentig, toen deze politiek op haar beurt plaats moest maken voor wat de 'derde weg' is gaan heten. Volgens Mudge werd de sociaaldemocratie in deze periode 'geneoliberaliseerd'. Het levert een bij eerste lezing indrukwekkend boek op, dat bij nadere beschouwing echter vragen oproept.

Ondanks de wat academische stijl leest het boek van Mudge als een klassieke detective. Direct in de inleiding worden bovengenoemde breuken 
geïdentificeerd, om vervolgens op zoek te gaan naar daders en omstanders. Wie waren nu verantwoordelijk voor deze ideologische transformaties en waarom waren ze zo invloedrijk? Het zijn uiteindelijk economische en politieke experts, actief in de verschillende partijen, die Mudge aanwijst als 'daders'. Dit laatste overigens zonder hen expliciet in de beklaagdenbank te zetten. Het boek wil een feitelijke analyse van het verleden bieden, zonder daar al te veel oordelen aan te verbinden. In interviews, waaronder een aantal maanden geleden in de Volkskrant, is de auteur op dat punt overigens wel wat stelliger, vooral waar het gaat om wat zij de neoliberalisering van de sociaaldemocratie noemt. Dat was, achteraf beschouwd, een enorme vergissing. Een ideologische heroriëntatie van links is dan ook hoognodig.

Daar die gedachten wat al te ver afdwalen van de veilige wegen van de historische analyse is Mudge op dat punt in haar boek zoals gezegd terughoudend. Dat neemt nietwegdatzijvoor hethedendaagsedebatoverdetoekomstvandesociaaldemocratie twee uiterst fundamentele inzichten formuleert. Het eerste is dat ideeën ertoe doen in de politiek. Zowel de transformatie in de jaren dertig als die in de jaren negentig was een gevolg van een verschuiving in de dominante analyse van staat en samenleving. Zij werden dus niet (alleen) ingegeven door electorale of macro-economische en wereldhistorische verschuivingen, waarna de sociaaldemocratische politiek zich maar had aan te passen. Het begrip 'neoliberalisering' is bij Mudge niet voor niets een werkwoord.

Tweede inzicht is dat een politieke partij meer was en ook behoort te zijn dan een soort uitzendbureau voor politici. Politieke en economische experts speelden in die partijen een belangrijke rol. Soms als lid van invloedrijke denktanks, dan weer vanuit academische posities, maar telkens in verbinding en verwantschap met de partij, haar voorlieden en leden. Het knappe van Mudge is dat zij inziet dat zowel politieke ideeënvorming als de daarvoor benodigde infrastructuur als zodanig belangrijk blijven, ondanks de in haar ogen verkeerde afslag die in de jaren negentig met de zogenoemde derde weg genomen werd. Toen mochten verschillende ideologen en experts de verschillende partijen in retrospectief de verkeerde kant op gestuurd hebben, dat wil niet zeggen dat het niet opnieuw aan hen overgelaten kan worden zelfbeeld en koers te doen veranderen. Een politieke partij, zo lijkt de boodschap, heeft eigenlijk geen andere keuze.

Toch zit er ook een fundamenteel probleem in het boek van Mudge. Het geeft een soms verwarrend antwoord op de vraag wat we eigenlijk onder 'politiek' moeten verstaan. $\mathrm{Nu}$ is het een open deur te stellen dat politiek in eerste instantie gaat over de vraag wat (en waar) politiek eigenlijk is. Maar Mudge is in haar analyse te vaag over wat ze onder politiek verstaat. Zowel bestuurders en parlementariërs als ideologen en academici worden door haar aangeduid als 'politici'. Pas in haar conclusie legt Mudge vervolgens uit dat zij onder politiek in eerste instantie een wijze van spreken verstaat. Dit discours veranderde fundamenteel op voornoemde breukmomenten, zowel waar het ging om de manier waarop sociaaldemocratische politici over zichzelf en hun partij spraken als hun denken over staat 
en samenleving.

Deze benadering van politiek gaat echter voorbij aan het gegeven dat naast het formuleren van ideologische uitgangspunten politiek toch ook gaat om het verwerven van macht en het formuleren en (doen) uitvoeren van beleid. Politiek is meer dan spreken alleen en bij Mudge is de verhouding tussen aandacht voor dat wat politici zeggen en dat wat ze doen een beetje zoek. Dat wreekt zich naar mijn oordeel bijvoorbeeld in haar analyse van de derde weg. Er is veel aandacht voor de vermeende invloed van neoliberale denkbeelden die de auteur toeschrijft aan ideologen als Anthony Giddens, maar hoe het beleid van de regeringen Blair zich daartoe verhield blijft onduidelijk. Waren maatregelen rondom minimumloon en gezondheidszorg van diens regeringen nu echt te typeren als 'neoliberaal'?

De in de inleiding met grote stelligheid naar voren gebrachte breukmomenten krijgen bovendien een schier onaantastbare status en geven de complexe en veelvormige geschiedenis die wordt verteld een prettige eenvoud. Maar zo simpel kan het toch niet geweest zijn? Participanten in het debat in en rond sociaaldemocratische partijen konden toch onmogelijk voorzien wie uit een ideeënstrijd als winnaar naar voren zou komen? En waren de door Mudge omschreven breukmomenten in de jaren dertig en negentig echt zo veel fundamenteler dan de opkomst van het revisionisme rond de eeuwwisseling en de stromen rond verschillende vormen van jeugdig engagement samengebracht onder de noemer New Left in de jaren zestig? Het zijn vragen die nergens echt gethematiseerd worden, waardoor de door Mudge geformuleerde analyse wat finalistisch over komt.

Zo lijkt bij nadere beschouwing de kracht van Leftism Reinvented ook direct de zwakte. Het heldere betoog geeft het boek een aantrekkelijke stelligheid, maar uiteindelijk roept de naar voren gebrachte analyse toch vooral nieuwe vragen op. De breed ingezette vergelijking maakt het boek bovendien kwetsbaar voor detailkritiek. Tegelijkertijd worden paralellen blootgelegd tussen de debatten in verschillende landen en wordt duidelijk dat veelvuldig leentjebuur gespeeld werd. Een vraag daarbij is overigens nog wel waar nu het zwaartepunt in het internationale debat precies lag. Dat leek voor de jaren dertig vooral in Duitsland te liggen, maar na de Tweede Wereldoorlog langzaamaan in Angelsaksische richting te verschuiven. Het is jammer dat Mudge die verschuiving weinig thematiseert.

Een interessante vraag is vervolgens in hoeverre de ontwikkelingsgang van de Nederlandse sociaaldemocratie in het door Mudge geformuleerde raamwerk past. Voor waar het de breuk in de jaren dertig betreft, zijn een aantal zaken wel herkenbaar. Met het Plan van de Arbeid (1935) en het nieuwe beginselprogramma dat SDAP in 1937 vaststelde, is de in de jaren dertig gesignaleerde breuk ook in Nederland zichtbaar. De vraag is echter of het vooral economisch experts waren die toon en tempo van het debat bepaalden. Naast mannen als Hein Vos en Jan Tinbergen valt immers toch ook te denken aan de jurist Marinus van der Goes van Naters, de theoloog Willem Banning, de historicus Herman Wiardi Beckman en jeugdleider en partijvoorzitter Koos Vorrink. Het debat ging over meer dan economie alleen en daarin was Nederland volgens mij geen uitzondering. 
In de politieke debatten in de jaren tachtig en negentig lijken economisch experts doorslaggevender, maar is de vraag voor de Nederlandse situatie gerechtvaardigd in hoeverre zij nog te kwalificeren zijn als onderdeel van een partijstructuur. Instituten als het Centraal Planbureau (CPB), het Sociaal en Cultureel Planbureau (SCP) en het Centraal Bureau voor de Statistiek (CBS) werden in de naoorlogse jaren stapsgewijs steeds belangrijker in het formuleren van de bandbreedte van het politieke en economische debat in Nederland. Wie buiten de kaders van met name het CPB wilde denken, had eigenlijk per definitie iets uit te leggen.

Wellicht was voor de Partij van de Arbeid in de jaren tachtig en negentig wel problematischer dat het eigen vlechtwerk van organisaties dat vanaf het einde van de negentiende eeuw als een soort steigerwerk rondom de partij gebouwd was, in de jaren zestig als het ware overbodig verklaard werd. Het ontbreken van een krachtige, eigen ideologische tegenmacht wreekte zich vervolgens toen het neoliberalisme als visie op politiek en samenleving ook in Nederland aan een opmars naar ideologische dominantie begon. En ook hier zou ik de stelling wel aandurven dat in naam neutrale instituties vergelijkbaar met het CPB, SCP en CBS ook in de door Mudge behandelde landen grote invloed hadden op het politieke spreken.

Voor de historiografie van de sociaaldemocratie betekent het boek van Mudge desalniettemin een belangrijke stap voorwaarts. Want ondanks dat de werkdefinitie van een cruciaal begrip als 'politiek' niet door het hele betoog even helder is, en de analyse op punten wat finalistisch overkomt, is er veel bijeengebracht. De auteur is zeer zeker meester over haar materiaal. Bovendien is met haar analyse niet alleen het debat over het verleden van de sociaaldemocratie verder gebracht, maar ook dat over de toekomst ervan. En dat is voor een historiserende studie een knappe prestatie.

\section{Maarten van den Bos}

Maarten van den Bos is historicus en werkt als ambtelijk secretaris voor de Banning Vereniging. Onlangs verscheen van zijn hand Geloven in het ideaal. Geschiedenis en actualiteit van de Arbeidersgemeenschap der Woodbrookers (Verloren, 2019). 